FAO (1957). FAO Nutr. Stud. no. I6.

FAO (1965). FAO Nutr. Mtg Rep. Ser. no. 37.

Fomon, S. J. (1967). Infant Nutrition. Philadelphia and London: W. B. Saunders.

Gopalan, C. \& Rao, N. (1966). F. Nutr. 9o, 213.

James, W. H. (1960). Fedn Proc. Fedn Am. Socs exp. Biol. 19, Ioog.

League of Nations (1936). Report on the Physiological Basis of Nutrition. No. A. I2(a) I936 II B.

McKay, D. (1912). The Protein Element in Nutrition. London: Edward Arnold.

Miller, D. S. \& Donoso, G. (1965). F. Sci. Fd Agric. 14, 345.

Miller, D. S. \& Mumford, P. (1967). Am. F. clin. Nutr. 20, г 212.

Miller, D. S. \& Payne, P. R. (I961a). Br. F. Nutr. 15, i I.

Miller, D. S. \& Payne, P. R. (1961 b). F. Nutr. 74, 413.

Miller, D. S. \& Payne, P. R. (I96rc). \%. Nutr. 75, 225.

Miller, D. S. \& Payne, P. R. (1964). Proc. Nutr. Soc. 23, 1 I.

Miller, D. S. \& Payne, P. R. (1968). Expl Geront. 3, 231.

Mitchell, H. H., Hamilton, T. S., Steggerda, F. R. \& Bean, H. W. (1945). F. biol. Chem. 158, 625.

Munro, H. N. (I g68). In Single-Cell Protein. [R. I. Mateles and S. R. Tannenbaum, editors.] Cambridge, Massachusetts and London: The M.I.T. Press.

Naismith, D. J. (1969). Proc. Nutr. Soc. 28, 25.

National Research Council (I953). Publs natn. Res. Coun., Wash. no. 302.

Orraca-Tetteh, R. (1964). PhD thesis, University of London.

Pavy, F. W. (1874). Food and Dietetics. New York: William Wood \& Co.

Platt, B. S., Dema, I. S. \& Miller, D. S. (1960). Proc. Nutr. Soc. 19, xi.

Rose, W. C. \& Wiscom, R. L. (1955). F. biol. Chem. 2r7, 997.

Rubner, M. (1903). Handbuch der Ernährungstherapie. $\mathbf{1}, 153$.

Sherman, H. C., Gillett, L. H. \& Osterberg, E. (1920). F. biol. Chem. 4r, 97.

Sivén, V. O. (1901). Skand. Arch. Physiol, II, 308.

Smith, E. (1863). Report to the Privy Council on the Food of the Labouring Classes.

Tanner, J. M., Whitehouse, R. H. \& Takaishi, M. (1966). Archs Dis. Childh. 4I, 6r 3.

Terroine, E. F. (1936). Q. Bull. Hlth Org. L. of N. no. 5, p. 427.

United Kingdom Department of Health and Social Security (1969). Rep. publ. Hlth med. Subj., Lond. no. 120.

Voit, C. (1881). Handbuch der Physiologie. 6, 519.

Young, V. R., Hussein, M. A. \& Scrimshaw, N. S. (I968). Nature, Lond. 218, 568.

\title{
Enzymes and the assessment of protein nutrition
}

\section{By J. C. Waterlow and Joan M. L. Stephen, * Medical Research Council Tropical Metabolism Research Unit, University of the West Indies, Kingston, Jamaica}

This symposium is concerned with the assessment of protein nutritional status in man. The question we have to examine is whether measurements of enzyme activity are, or may be in the future, of any value for this purpose. There are several concepts which may be useful in considering this problem, such as the nature of enzymes and the regulation of their amount in the body, the effect on activity of a biochemical lesion at the cellular level, and the adaptive changes that reflect an altered balance of metabolic pathways.

Since enzymes are themselves proteins it seems logical to expect that in general a fall in the amount of dietary protein might be reflected in a reduction in the amounts of enzymes in blood or tissues. Furthermore, many enzymes depend for their action on trace metals or vitamins of the B complex (for example, riboflavine, pyridoxine), all of which may be in short supply when protein is scarce. One might hope, therefore, that measurements of enzyme activity would provide a useful tool for assessing

\footnotetext{
*Seconded to the Department of Health and Social Security, London.
} 
the state of protein nutrition. This was the earliest concept, which inspired a large body of work in the I 95 os. The results obtained in animals were reviewed by Knox, Auerbach \& Lin (1956), and in man by Waterlow (1959).

\section{Enzyme studies in man}

In human subjects for obvious practical reasons, measurements of enzyme activity have most often been made on serum or plasma, and this imposes a serious limitation on the range of enzymes that can be studied. A few investigations have also been made on enzymes in liver specimens obtained by biopsy from malnourished infants, but no clear picture emerged from this earlier work, nor was it capable of practical application. For example, in the rat the level of xanthine oxidase in the liver is extremely sensitive to variations in dietary protein (Litwack, Williams, Chen \& Elvehjem, 1952; Muramatsu \& Ashida, 1962), to such an extent that its measurement has been suggested as a criterion of protein quality. Burch, Arroyave, Schwartz, Padilla, Béhar, Viteri \& Scrimshaw (1957) found a large reduction in the activity of this enzyme in the livers of children with kwashiorkor: the average value was $2 \cdot 6$ units, compared with 6.9 after recovery. This, however, is not the kind of measurement that can be made in routine surveys. In recent years methods have been improved for collecting undamaged white blood cells. The work of $\mathrm{O}$. Pineda (personal communication) suggests that the metabolic behaviour of these cells is similar to that of liver, so that with modern micro-techniques the range of possible enzyme measurements is greatly extended.

It is disappointing from the practical point of view that urine has not proved more useful as a material for enzyme measurements in protein malnutrition. The only recent reports of urinary measurements that we know of are those of amylase (Du Plessis, Vivier \& De Lange, I967) and of the aryl sulphatases (Ittyerah, Dumm $\&$ Bachhawat, 1967$)$. It is doubtful if the results have any direct relevance to protein nutrition.

Recent work on some serum enzymes in protein malnutrition is summarized in Table $\mathbf{r}$. The majority of the studies were made in infants or young children, since this is the age at which protein deficiency is most common, leading to the clinical picture of kwashiorkor.

Pseudo-cholinesterase (EC 3.I.I.8, acylcholine acyl-hydrolase) is the enzyme that has perhaps been most often measured and was the first found to be reduced in protein malnutrition (McCance, Widdowson \& Hutchinson, r948; Waterlow, 1950). Waterlow (1959) regarded it as a more sensitive index in malnourished infants than the level of serum proteins. This was also the finding of Hutchinson, McCance \& Widdowson (I95I) when they studied cholinesterase in sera from ex-prisoners of war in Germany. The reduction was greater in subjects with oedema than in those without. Montgomery $(1963)$ also found very low values in children with oedema.

Enzymes appearing in the plasma must have been synthesized elsewhere, and are sometimes specific for a particular organ or tissue. Pseudo-cholinesterase is synthesized in the liver, although its function is not known. Alkaline phosphatase 
Table I. Effect of protein malnutrition on the activity of serum enzymes

\section{Subjects \\ (I) Malnourished children}

\begin{tabular}{ll}
$\begin{array}{l}\text { Alkaline } \\
\text { phosphatase }\end{array}$ & Reduced \\
$\begin{array}{l}\text { Esterase } \\
\text { (non-specific) }\end{array}$ & $\begin{array}{l}\text { Reduced in } \\
\text { kwashiorkor } \\
\text { Slightly reduced } \\
\text { in marasmus }\end{array}$ \\
Amylase & $\begin{array}{l}\text { Reduced in } \\
\text { kwashiorkor }\end{array}$ \\
& $\begin{array}{l}\text { Unchanged in } \\
\text { marasmus } \\
\text { Reduced in } \\
\text { kwashiorkor } \\
\text { Unchanged in } \\
\text { marasmus } \\
\text { Increased }\end{array}$ \\
\hline Lipase &
\end{tabular}

(2) Malnourished adults

(3) Marginally malnourished preschooland schoolchildren

\begin{abstract}
Enzyme
Pseudo-
\end{abstract} cholinesterase

Effect on activity

Reduced

Increased

Unchanged

Isocitric

dehydrogenase

Lactic

dehydrogenase

Pseudo-

cholinesterase

Pseudo-

cholinesterase

Increased

Reduced

Unchanged
Authors

Waterlow (1950)

Dean \& Schwartz (1953)

Baron (1960)

Edozien (196i)

Schendel et al. (1962)

Montgomery (1963)

Dean \& Schwartz (1953)

Edozien (196r)

Sandstead et al. (1965)

Dean \& Schwartz (1953)

Srikantia et al. (1964)

Srikantia et al. (1964)

Dean \& Schwartz (1953)

Edozien (196r)

Srikantia et al. (1964)

Srikantia et al. (1964)

Srikantia et al. (1964)

Srikantia et al. (1964)

Baron ( 1960$)$

Edozien (196I)

McLean (1962)

Smith (I 962)

Sandstead et al. (1965)

McLean (1962)

Sandstead et al. (1965)

Hutchinson et al. (I95I)
Arroyave et al. (1958)

Béhar et al. (1960)

(EC 3.I.3.I, orthophosphoric monoester phosphohydrolase) may be derived from a number of different organs: liver, bone, kidney and intestine, but that found in the plasma of young children is probably mostly of bone origin. In normal growing infants and at puberty levels are higher than in adults because of rapid skeletal growth. In protein-deficient children who are not growing plasma alkaline phosphatase is low, and so is the excretion of hydroxyproline peptides. These effects point to a decreased rate of formation and remodelling of the bone matrix. Lipase and amylase are produced in the pancreas and in malnutrition their concentration in the pancreatic juice is reduced (Thompson \& Trowell, 1952) and levels in the plasma are low. The exocrine pancreas normally has a very high rate of protein synthesis, and perhaps for that reason enzyme production and secretion may be very sensitive to a reduction in the rate of amino acid supply.

All the examples of reduction in enzyme activity referred to so far have been used as corroborative evidence of the existence of fairly acute and possibly short- 
term protein deficiency. The measurements would be of greater practical importance if it could be shown that they provide particularly sensitive indices of the more marginal states of protein nutrition. Very few studies have been done with this objective.

Table I shows only two examples of the use of enzyme measurement-that of pseudocholinesterase-in nutritional survey work, both done at the Institute of Nutrition for Central America and Panama. Arroyave, Feldman \& Scrimshaw (1958) found pseudocholinesterase activity bore no relation to socioeconomic level or nutritional status in groups of preschool children and of schoolchildren in Central America. These workers concluded that serum cholinesterase was not sensitive enough to assess nutritional status, and that the physical measurements-height, weight, skinfold thickness-were much more useful in evaluating dietary patterns. They thought that the decrease in cholinesterase activity found in children with kwashiorkor was probably a sudden event occurring after the clinical signs of protein malnutrition had begun to develop. In a further study of preschool children, who were underweight and under-height for their age and who were eating small amounts of animal protein, the serum cholinesterase levels were almost all within the normal range and there was no evidence of a relationship between the enzyme values and total serum proteins (Béhar, Arroyave, Flores \& Scrimshaw, 1960).

Other people have tried to correlate enzyme activity with another index of nutritional status such as serum albumin or total serum proteins, although these may not be the best indicators to look for in marginal protein malnutrition, One of the adaptations made by the body to a low protein intake is the maintenance of its serum albumin level (Waterlow, I968); this only decreases significantly after clinical changes appear (Whitehead, 1967). Schendel, Hansen \& Brock (1962), however, found a statistically significant correlation between serum albumin and serum cholinesterase in a series of 127 children in various states of protein nutrition. Edozien (196r), on the other hand, found a correlation between alkaline phosphatase and serum albumin in children with kwashiorkor, but none between cholinesterase and either serum albumin or total proteins.

The discrepancies between the findings of different workers suggest that there are other factors operating besides deficiency of protein. Protein malnutrition is well known to be a poorly defined state and can be coupled with any degree of calorie malnutrition at the same time. Experimental work has shown (Schimke, 1962a; Harper, 1965) that low-protein diets and total starvation alter enzyme activities in opposite directions, and the effect of a mixed deficiency may greatly increase the difficulty of interpreting any changes that are found. This may explain the results of Srikantia, Jacob \& Reddy (1964), who found that amylase, lipase and esterase were all reduced in children with kwashiorkor, but were normal or nearly so in marasmic children. In recent work in Pretoria (Du Plessis et al. 1967) on four different racial groups of children, who were taking various amounts of fat and carbohydrate in their diet but roughly the same percentage of calories from protein, it was shown that as the proportion of carbohydrate in the diet increased so did the 
serum and urinary amylase. It is obviously an over-simplification to think in terms of protein only; the protein-calorie balance may be much more important.

There is another group of serum enzymes which fall into a completely different category from those mentioned above. These are enzymes that are apparently released into the blood from damaged or necrotic tissue, usually muscle or liver. The transaminases (aminotransferases) are the enzymes in this group which have received most attention. The serum levels have been found by some workers to be raised in malnourished children (Baron, I960; Edozien, I96I; McLean, I962); other authors have found no difference before and after treatment (Smith, 1962; Sandstead, Shukry, Prasad, Gabr, El Hifney, Mokhtar \& Darby, 1965). The increases, when they occur, probably depend on the amount of liver cell damage. Raised levels of isocitric dehydrogenase (L-isocitrate: NADP oxidoreductase) (McLean, I962) and of lactic dehydrogenase (L-lactate: NAD oxidoreductase) (Sandstead et al. 1965) have also been described; these again, in all probability, are a reflection of tissue injury.

These enzyme changes cannot be called characteristic of protein deficiency, except perhaps as a terminal event when cellular mechanisms have broken down. In kwashiorkor, failure of certain enzymatic links in the metabolism of aromatic amino acids can produce abnormal metabolites in the urine (Whitehead, 1964), and Waterlow (I96I) found that oxidative phosphorylation was reduced in the livers of malnourished children, especially when the liver was fatty. In both these instances the changes are probably late events; they may be important in determining whether the patient dies or survives, but they have little bearing on the practical problem: how to assess the milder degrees of protein deficiency or protein-calorie imbalance, and how to define the point at which the physiological change passes over into the pathological. Perhaps there will be more progress in the future towards the solution of the problem, since the factors that control the amounts of enzymes in blood and tissues are beginning to be better understood.

\section{The effect of protein intake on protein synthesis}

There is some experimental evidence to support the general assumption that a low protein intake should lead to a depression of protein synthesis. A number of workers have found that in vitro cell-free preparations from livers of protein-depleted rats incorporate amino acids into protein less efficiently than preparations from normal animals (Munro, I968; Wannemacher, Cooper \& Yatvin, r968). On the other hand, studies in the whole animal suggest that on a low-protein diet protein synthesis in the liver is protected at the expense of muscle (Waterlow \& Stephen, 1968).

Sidransky \& Verney (r964) found that force-feeding a diet designed to produce kwashiorkor in rats caused increased incorporation of amino acids into liver protein. In children total protein synthesis, measured by constant infusion of $\left[{ }^{15} \mathrm{~N}\right]$ glycine, was not altered by changes in the level of protein intake from $\mathrm{I} \cdot 2$ to $5 \cdot 2 \mathrm{~g}$ per $\mathrm{kg}$ per day (Picou \& Taylor-Roberts, I969), nor was the synthesis rate lower in malnourished than in recovered children. 
All these experiments refer to the rate of total protein synthesis in the whole body or in a particular tissue and merely reflect the average of a great many individual rates. The single protein whose turnover has been studied in the greatest detail is plasma albumin. It has been shown both in rats (Kirsch, Frith, Black \& Hoffenberg, 1968) and in children (James \& Hay, 1968) that the rate of albumin synthesis falls very rapidly when the dietary protein supply is reduced, while catabolic rate alters more slowly.

If enzyme proteins behaved like plasma albumin, one would expect them to be particularly severely affected by protein deficiency, since many of them turn over very rapidly, with half-lives of hours rather than days (Schimke, Ganschow, Doyle \& Arias, 1968), and therefore need to be renewed more quickly and more often. In fact, the same change in dietary protein intake may alter different enzymes concerned in amino acid metabolism in different directions according to functional needs. These adaptive changes cannot be reconciled with the simple concept that the rate of synthesis is controlled by the amino acid supply.

\section{Adaptive enzyme changes}

Experimental work in animals on adaptive changes in enzymes of amino acid metabolism was summarized in a valuable review by Harper (1965).

One of the most striking examples of enzyme adaptations was demonstrated by Schimke (1962a) when he found that urea-cycle enzymes are increased by highprotein feeding or starvation and decreased by low-protein diets. High-protein diets cause great increases in some other enzymes concerned with the catabolism or disposal of amino acids, for example, threonine and serine dehydratases (Pitot \& Peraino, I964; Jost, Khairallah \& Pitot, I968). In one case-tryptophan pyrrolase-induction by the specific substrate tryptophan has been established without doubt, but in other instances the requirements for enzyme induction seem to be less clear (Harper, I965; Peraino, Blake \& Pitot, I965). Less attention has been given to the effects of low-protein feeding on these enzymes, but Fallon, Hackney \& Byrne (I966) found that serine dehydratase activity in the liver was reduced to zero in rats fed a $2 \%$ casein diet.

There are also examples of the contrary effect - of enzymes whose activity is enhanced by protein deprivation. These are the enzymes on the synthetic pathway. Mariani, Spadoni \& Tomassi ( 1963 ) showed that amino acid activating enzymes (synthetases) in the liver are increased three to four times in rats fed on protein-free diets. When protein-depleted rats are refed, the synthetases fall to normal levels in 3-4 days (Stephen, 1968). Another example is the many-fold increase in activity of 3-phosphoglycerate dehydrogenase, an enzyme of serine biosynthesis, in the livers of rats transferred from a high-protein to a low-protein diet (Fallon et al. 1966).

In a number of cases specific enzyme proteins have been isolated by immunochemical methods, and it has been shown that changes in activity result from real changes in the amount of enzyme. Evidence obtained with inhibitors of protein synthesis and by measurement of half-lives indicates that these changes in amount 
result mainly from alterations in the rate of enzyme synthesis (Schimke, I964; Schimke, Sweeney \& Berlin, 1965; Rowe \& Wyngaarden, 1966; Rechcigl, 1968; Jost et al. 1968; Schimke et al. 1968). Stabilization by substrate may also play a part in reducing the rate of catabolism of the enzyme protein (Schimke, 1964). An interesting aspect of this experimental work is the specificity of the response of the enzyme to some inducers and inhibitors; for example, glucose inhibits the increase in serine dehydratase ( $E C$ 4.2.1.13, L-serine hydrolyase) produced by feeding casein hydrolysate, but it stimulates the incorporation of amino acids into total liver protein and albumin (Jost et al. I968).

One may ask what relevance these experimental studies have to the assessment of human protein nutrition. We have obtained some evidence that adaptive enzyme changes occur in man as well as in the rat. In the livers of malnourished children the activity of synthetases was increased and that of argininosuccinate lyase decreased compared with the levels found after recovery (Stephen \& Waterlow, 1968). However, the range over which these enzymes vary and the rate at which adaptation occurs appears to be less than with some other enzymes. Table 2 shows that in

Table 2. Changes in enzymes of amino acid metabolism in the liver produced by alterations in dietary protein intake

\begin{tabular}{|c|c|c|c|c|c|}
\hline $\begin{array}{l}\text { Feeding } \\
\text { regime }\end{array}$ & Enzyme & Dietary change & $\begin{array}{l}\text { Time } \\
\text { (days) }\end{array}$ & $\begin{array}{c}\text { Activity } \\
\text { ratio } \\
\text { (final: } \\
\text { initial) }\end{array}$ & Authors \\
\hline \multirow{7}{*}{$\begin{array}{l}\text { (I) High- } \\
\text { protein }\end{array}$} & Serine & $2 \%-88 \%$ casein & 7 & 110 & Fallon et al. (1966) \\
\hline & $\begin{array}{l}\text { Threonine } \\
\text { dehydratase }\end{array}$ & chow $-90 \%$ casein & 7 & 108 & Pitot \& Peraino (1964) \\
\hline & $\begin{array}{l}\text { Threonine } \\
\text { dehydratase }\end{array}$ & $4 \mathrm{~g}$ casein hydrolysate & I & 300 & Pitot \& Peraino ( 1964$)$ \\
\hline & $\begin{array}{l}\text { Glutamicpyruvic } \\
\text { transaminase }\end{array}$ & $15 \%-60 \%$ casein & 14 & $2 \cdot 7$ & Schimke (1962b) \\
\hline & Arginase & $15 \%-60 \%$ casein & I4 & $2 \cdot 2$ & Schimke ( $1962 b)$ \\
\hline & Xanthine oxidase & $8 \%-23 \%$ casein & 3 & $6 \cdot 7$ & $\begin{array}{l}\text { Rowe \& Wyngaarden } \\
\text { (1966) }\end{array}$ \\
\hline & $\begin{array}{l}\text { 3-Phospho- } \\
\text { glycerate } \\
\text { dehydrogenase }\end{array}$ & $2 \%-88 \%$ casein & 7 & 0.05 & Fallon et al. (1966) \\
\hline \multirow[t]{5}{*}{$\begin{array}{l}\text { (2) Low- } \\
\text { protein }\end{array}$} & $\begin{array}{l}\text { 3-Phospho- } \\
\text { glycerate } \\
\text { dehydrogenase }\end{array}$ & $25 \%-2 \%$ casein & 7 & $13 \cdot 6$ & Fallon et al. (1968) \\
\hline & Synthetases & $20 \%-0 \%$ casein & I5 & 2.9 & Mariani et al. ( $\left.\mathrm{rg}^{6} 3\right)$ \\
\hline & Arginase & $15 \%-0 \%$ casein & 4 & 0.8 & Schimke (1962a) \\
\hline & Argininosuccinase & I5\%-o\% casein & 4 & 0.4 & Schimke (1962a) \\
\hline & Serine dehydratase & chow $-2 \%$ casein & 7 & 0.35 & Fallon et al. (1966) \\
\hline
\end{tabular}

animal experiments increases of more than a hundredfold can be produced in as short a time as $24 \mathrm{~h}$, although admittedly the conditions used were not always physiological. The experimental work may, therefore, act as a guide to measurements which will provide earlier and more sensitive indices of protein depletion. 


\section{Conclusion}

In the past too little attention has been paid to the functional significance of the enzyme changes which have been found in man. The experimental studies emphasize the importance of a physiological approach. We have to distinguish between the effects of a low level of protein intake and the effects of protein depletion-in other words, between adaptation and breakdown. This can only be achieved by a better understanding of the mechanisms of adaptation (Waterlow, i 968). The marginal malnutrition which we look for in survey work belongs to the stage of adaptation. As Schimke (1962b) has pointed out, adaptation to changes in diet of the mammal is not limited to a few special instances, but is a continuous process involving major pathways of metabolism. Enzymic adaptations must play a very important part, if not the main part, in these metabolic regulations (Mitchell, I964). The application of these ideas to the human problem is a challenge to biochemists working in this field.

\section{REFERENCES}

Arroyave, G., Feldman, R. \& Scrimshaw, N. S. (1958). Am. F. clin. Nutr. 6, I64.

Baron, D. N. (1960). F. clin. Path. r3, 252.

Béhar, M., Arroyave, G., Flores, M. \& Scrimshaw, N. S. (1960). Br. F. Nutr. 14, 217.

Burch, H. B., Arroyave, G., Schwartz, R., Padilla, A. M., Béhar, M., Viteri, F. \& Scrimshaw, N. S. (1957). F. clin. Invest. 36, I 579.

Dean, R. F. A. \& Schwartz, R. (1953). Br. F. Nutr. 7, I31.

Du Plessis, J. P., Vivier, F. S. \& De Lange, D. J. (1967). S. Afr. med. F. 41, 1216.

Edozien, J. C. (1961). Pediatrics, Springfield 27, 325.

Fallon, H. J., Davis, J. L. \& Goyer, R. A. (1968). F. Nutr. 96, 220.

Fallon, H. J., Hackney, E. J. \& Byrne, W. L. (1966). Y. biol. Chem. 241, 4157.

Harper, A. E. (1965). Can. F. Biochem. 43, I 589.

Hutchinson, A. O., McCance, R. A. \& Widdowson, E. M. (1951). Spec. Rep. Ser. med. Res. Coun., Lond. no. 275 .

Ittyerah, T. R., Dumm, M. E. \& Bachhawat, B. K. (1967). Clin. chim. Acta 17, 405.

James, W. P. T. \& Hay, A. M. (1968). F. clin. Invest. 47, 1958.

Jost, J-P., Khairallah, E. A. \& Pitot, H. C. (I968). F. biol. Chem. 243, $3 \circ 57$.

Kirsch, R., Frith, L., Black, E. \& Hoffenberg, R. (1968). Nature, Lond. 217, 578.

Knox, W. E., Auerbach, V. H. \& Lin, E. C. C. (1956). Physiol. Rev. 36, I64.

Litwack, G., Williams, J. N. Jr, Chen, L. \& Elvehjem, C. A. (1952). $\mathscr{F}$. Nutr. 47, 299.

McCance, R. A., Widdowson, E. M. \& Hutchinson, A. O. (1948). Nature, Lond. 16r, 56.

McLean, A. E. M. (1962). Lancet ii, 1292.

Mariani, A., Spadoni, M. A. \& Tomassi, G. (1963). Nature, Lond. 199, 378.

Mitchell, H. H. (1964). In Nutrition. Ch. 6, p. 35 I. [G. H. Beaton and E. W. McHenry, editors.] New York and London: Academic Press, Inc.

Montgomery, R. D. (1963). Archs Dis. Childh. 38, 343.

Munro, H. N. (1968). Fedn Proc. Fedn Am. Socs exp. Biol. 27, 1231.

Muramatsu, K. \& Ashida, K. (1962). F. Nutr. 76, 143.

Peraino, C., Blake, R. L. \& Pitot, H. C. (1965). F. biol. Chem. 240, 3039.

Picou, D. \& Taylor-Roberts, T. (1969). Clin. Sci. 36, 283.

Pitot, H. C. \& Peraino, C. (1964). F. biol. Chem. 239, 1783.

Rechcigl, M. Jr (1968). Enzymologia 34, 23.

Rowe, P. B. \& Wyngaarden, J. B. (r g66). \%. biol. Chem. 24I, 557 I.

Sandstead, H. H., Shukry, A. S., Prasad, A. S., Gabr, M. K., El Hifney, A., Mokhtar, N. \& Darby, W. J. (1965). Am. F. clin. Nutr. 17, 15.

Schendel, H. E., Hansen, J. D. L. \& Brock, J. F. (1962). S. Afr. F. Lab. clin. Med. 8, 23.

Schimke, R. T. (1 962a). F. biol. Chem. 237, 192 r.

Schimke, R. T. (1962b). J. biol. Chem. 237, 459 . 
Schimke, R. T. (1964). F. biol. Chem. 239, 3808.

Schimke, R. T., Sweeney, E. W. \& Berlin, C. M. (1965). F. biol. Chem. 240, 322.

Schimke, R. T., Ganschow, R., Doyle, D. \& Arias, I. M. (1968). Fedn Proc. Fedn Am. Socs exp. Biol. 27, 1223 .

Sidransky, H. \& Verney, E. (1964). Archs Path. 78, I34.

Smith, C. E. (1962). F. Pediat. 6r, 617.

Srikantia, S. G., Jacob, C. M. \& Reddy, V. (1964). Am. J. Dis. Child. 107, 256.

Stephen, J. M. L. (I 968 ). Br. F. Nutr. 22, 153.

Stephen, J. M. L. \& Waterlow, J. C. (1968). Lancet i, I 8.

Thompson, M. D. \& Trowell, H. C. (1952). Lancet i, I031.

Wannemacher, R. W. Jr, Cooper, W. K. \& Yatvin, M. B. (1968). Biochem. F. ro7, 6r 5.

Waterlow, J. C. (1950). Lancet i, 908.

Waterlow, J. C. (1959). Fedn Proc. Fedn Am. Socs exp. Biol. 18, I 143.

Waterlow, J. C. (I 96I). Proc. R. Soc. B I55, 96.

Waterlow, J. C. (1968). Lancet ii, I09I.

Waterlow, J. C. \& Stephen, J. M. L. (1968). Clin. Sci. 35, 287.

Whitehead, R. G. (r964). Clin. Sci. 26, 271, 279.

Whitehead, R. G. (1967). Clin. Pediat. 6, 516.

\section{Protein nutrition and wound healing}

\section{By J. S. Garrow, Medical Research Council, Department of Obstetrics, Royal Free Hospital, Liverpool Road, London, $N_{\mathbf{I}}$}

In normal young men, in whom the calorie requirements are fully met, an intake of about $5 \circ \mathrm{g}$ protein per day promotes nitrogen balance, and little additional storage results even from much larger protein intakes (Calloway \& Spector, I954). Chittenden maintained that an adult who adopted the intake of $120 \mathrm{~g}$ per day suggested by Voit, or who advised others to do so, was 'encouraging individual and racial suicide' (Cathcart, 1912), and the animal experiments of Ross show that by all objective criteria, except that of body-weight, the rats whose dietary intake is restricted fare better than those allowed unlimited quantities of a diet of good quality (Ross, 196I ; Ross \& Bras, 1965).

Most people, however, believe that it is a good thing to have 'plenty' of protein in the diet, rather than just enough. Underlying this belief is the concept of labile protein reserves which, although they may not be very large, or even very useful in normal circumstances, may give the 'well-fed' animal some sort of advantage in times of stress. The magnitude of the labile protein pool in normal adults is probably less than $1 \%$ of the total body protein (Young, Hussein $\&$ Scrimshaw, I968), and in children who are treated for malnutrition this pool does not significantly increase in size (relative to body-weight) as the child recovers (Chan, I968). Waterlow (I968) concludes that labile protein is not in any sense a reservoir, but merely the result of a time lag in the adjustment of synthetic and catabolic rates after a change in protein intake. However, the possibility remains that the state of adaptation associated with a high protein intake might offer biological advantages over that which enables equilibrium to be maintained on minimal dietary protein. The particular biological advantage with which this paper is concerned is the healing of wounds of the skin in human subjects. 